Article

\title{
Evaluation of the Cultivated Mushroom Pleurotus ostreatus Basidiocarps Using Vibration Spectroscopy and Chemometrics
}

\author{
Ekaterina Baeva ${ }^{1,+}{ }^{\dagger}$, Roman Bleha ${ }^{1,+}{ }^{\dagger}$, Markéta Sedliaková ${ }^{2}$, Leonid Sushytskyi ${ }^{1}$, Ivan Švec ${ }^{1}$, \\ Jana Čopíková ${ }^{1}$, Ivan Jablonsky ${ }^{3}$, Pavel Klouček ${ }^{4}$ and Andriy Synytsya ${ }^{1, * \mathbb{D}}$ \\ 1 Department of Carbohydrates and Cereals, Faculty of Food and Biochemical Technology, \\ University of Chemistry and Technology in Prague, Technická 5, 6 Dejvice, 16628 Prague, Czech Republic; \\ ekaterina.baeva@vscht.cz (E.B.); roman.bleha@vscht.cz (R.B.); leonid.sushytskyi@vscht.cz (L.S.); \\ sveci@vscht.cz (I.Š.); copikovj@vscht.cz (J.Č.) \\ 2 Nicolet CZ s. r. o., Klapálkova 2242/9, 11 Chodov, 14900 Prague, Czech Republic; sedliakova@nicoletcz.cz \\ 3 Department of Horticulture, Faculty of Agrobiology, Food and Natural Resources, \\ Czech University of Life Sciences Prague, Kamýcká 129, 6 Suchdol, 16500 Prague, Czech Republic; \\ jablonsky@af.czu.cz \\ 4 Department of Food Science, Faculty of Agrobiology, Food and Natural Resources, \\ Czech University of Life Sciences Prague, Kamýcká 129, 6 Suchdol, 16500 Prague, Czech Republic; \\ kloucek@af.czu.cz \\ * Correspondence: sinicaa@vscht.cz; Tel.: +420-22044-3116 \\ + Both authors contributed equally to the preparation of this article.
}

Received: 29 October 2020; Accepted: 16 November 2020; Published: 18 November 2020

\begin{abstract}
Fruiting bodies (basidiocarps) of the cultivated mushroom Pleurotus ostreatus (16 strains) were characterized by vibration spectroscopy and chemometrics. According to organic elemental analysis and Megazyme assay, the basidiocarps contained $\sim 6.2-17.5 \%$ protein and $\sim 18.8-58.2 \%$ total glucans. The neutral sugar analysis confirmed that glucose predominated in all the samples ( 71.3-94.4 mol\%). Fourier-transformed (FT) mid- and near-infrared (FT MIR, FT NIR) and FT Raman spectra of the basidiocarps were recorded, and the characteristic bands of proteins, glucans and chitin were assigned. The samples were discriminated based on principal component analysis (PCA) of the spectroscopic data in terms of biopolymeric composition. The partial least squares regression (PLSR) models based on first derivatives of the vibration spectra were obtained for the prediction of the macromolecular components, and the regression coefficients $R^{2}$ and root mean square errors (RMSE) were calculated for the calibration (cal) of proteins $\left(R_{\text {cal }}^{2} 0.981-0.994, \mathrm{RMSE}_{\mathrm{cal}} \sim 0.3-0.5\right)$ and total glucans $\left(R_{\text {cal }}^{2} 0.908-0.996, \mathrm{RMSE}_{\mathrm{cal}} \sim 0.6-3.0\right)$. According to cross-validation $(\mathrm{CV})$ diagnosis, the protein models were more precise and accurate $\left(R^{2}{ }_{\mathrm{cv}} 0.901-0.970, \mathrm{RMSE}_{\mathrm{cv}} \sim 0.6-1.1\right)$ than the corresponding total glucan models $\left(R_{\mathrm{cv}}^{2} 0.370-0.804, \mathrm{RMSE}_{\mathrm{cv}} \sim 4.7-8.5\right)$ because of the wide structural diversity of these polysaccharides. Otherwise, the Raman band of phenylalanine ring breathing vibration at $1004 \mathrm{~cm}^{-1}$ was used for direct quantification of proteins in P. ostreatus basidiocarps ( $R \sim 0.953)$. This study showed that the combination of vibration spectroscopy with chemometrics is a powerful tool for the evaluation of culinary and medicinal mushrooms, and this approach can be proposed as an alternative to common analytical methods.
\end{abstract}

Keywords: oyster mushroom; basidiocarps; proteins; $\beta$-D-glucans; vibrational spectroscopy; chemometrics

\section{Introduction}

Oyster mushrooms (genus Pleurotus) are among the most cultivated and consumed mushrooms in the world [1,2]. Their fruiting bodies (basidiocarps) are low in calories, fats and essential fatty acids, 
but contain large amounts of proteins with almost all of the essential amino acids, polysaccharides including soluble and insoluble glucans, dietary fibers, vitamins and minerals [3-5]. Basidiocarps and compounds derived from them have demonstrated evident medicinal impacts [6]. Polysaccharides, especially $\beta$-D-glucans, have positive effects on human health $[7,8]$. Various polysaccharides, mainly mannogalactans and glucans, have been isolated from Pleurotus mushrooms and characterized as biologically active compounds [9-14].

The specie Pleurotus ostreatus is the most common among all oyster mushrooms [15]. Basidiocarps of this mushroom had hypocholesterolemic effects in animal models and patients $[16,17]$ as well as potent antinociceptive effect in rats fed with it [18]. Antioxidant and anti-inflammatory activities of these basidiocarps were also reported $[19,20]$. A water-insoluble (1-3)- $\beta$-D-glucan, named "pleuran", obtained from P. ostreatus was the most studied polysaccharide of oyster mushrooms [21]. This glucan, as well as other polysaccharides isolated from this source, demonstrated many medicinal activities including immunomodulating [13,22], antitumor [23], antioxidant [10] and prebiotic [14] effects. Various strains of P. ostreatus with specific biopolymer compositions have been obtained for cultivation on various substrates [24].

Screening of crude basidiocarps originating from different strains of P. ostreatus is essential to evaluate the nutritional quality and prospects of these mushrooms for culinary use or as the source for preparation of food supplements. Methods of vibration spectroscopy have proved to be very useful in this respect [25]. These methods themselves and together with multivariate analyses have been applied to detect proteins, polysaccharides, proteins, sterols and aromatic compounds in fractions derived from basidiocarps of oyster mushrooms [14,26-29]. In addition, the combination of FTIR spectroscopy and multivariate analysis has been used for the discrimination of fungal samples of various origin, location and treatment [29-31].

The main purpose of this work was to evaluate the methods of vibration spectroscopy in the screening analysis of edible and medicinal mushrooms, primarily to characterize the biopolymer composition of fruiting bodies. The subject of the study was 16 samples of basidiocarp of various P. ostreatus strains promising for cultivation and gastronomic use. Sample discrimination was performed using principal component analysis (PCA) of spectroscopic data obtained by Fourier-transformed mid- and near-infrared (FT MIR, FT NIR) and FT Raman spectroscopic measurements. Partial least squares regression (PLSR) models were created to predict protein and total glucan contents based on the mentioned spectroscopic data.

\section{Materials and Methods}

\subsection{Basidiocarps of Chosen Strains}

Basidiocarps of the cultivated mushrooms P. ostreatus (16 strains) were obtained from mushroom grower in accordance with the Convention on Biological Diversity and the Convention on the Trade in Endangered Species of Wild Fauna and Flora that was confirmed by the Ethics Committee of the Czech University of Life Sciences Prague, the Czech Republic. All fungal material used in this study was cultivated based on the agreement by local grower within research project no. QK1910209 funded by the Ministry of Agriculture of the Czech Republic. The basidiocarp samples are specified in Table 1. Basidiocarps were mechanically cleaned, lyophilized and homogenized. To remove small molecules (mono- and oligosaccharides, lipids, phenolic compounds, etc.), the dry powdered samples were washed with $0.2 \mathrm{~mol} \mathrm{~L}^{-1}$ hydrochloric acid in $80 \%$ aq. ethanol, then neutralized by washing with $80 \%$ and $96 \%$ aq. ethanol and dried in air. The purified powdered samples of basidiocarps were used for analyses. All procedures performed within the framework of research projects no. QK1910209 and 21-SVV/2020 (Specific University Research, UCT Prague) and presented in this article followed the Code of Ethics of the University of Chemistry and Technology, Prague, as confirmed by Ethics Committee of this university. 
Table 1. Specification of the P. ostreatus basidiocarp samples.

\begin{tabular}{ccc}
\hline Sample & Strain & Supplier \\
\hline 2013 & 2013 & Mycelia nv (Deinze, Belgium) \\
2515 & 2515 & Mycelia nv (Deinze, Belgium) \\
3009 & 3009 & Sylvan Inc. (Kittanning, PA, USA) \\
3029 & 3029 & Sylvan Inc. (Kittanning, PA, USA) \\
3253 & 3253 & Sylvan Inc. (Kittanning, PA, USA) \\
fotios & fotios & Sylvan Inc. (Kittanning, PA, USA) \\
hk35 & HK35 & Sylvan Inc. (Kittanning, PA, USA) \\
kryos & KRYOS & Sylvan Inc. (Kittanning, PA, USA) \\
spoppo & SPOPPO & Sylvan Inc. (Kittanning, PA, USA) \\
po1 & PO1 & Unknown \\
po2 & PO2 & Unknown \\
po3 & PO3 & Unknown \\
po4 & PO4 & Unknown \\
po5 & PO5 & Unknown \\
po6 & PO6 & \\
p80 & P80 & Hollander Spawn BV (Horst, Holland) \\
\hline
\end{tabular}

\subsection{Elemental Analysis And Determination of Proteins}

Organic elemental analysis (C, H, N and S) was made on an Elementar vario EL III (Elementar, Germany). The accuracy of the method is determined for simultaneous analysis of $5 \mathrm{mg}$ of 4 -amino-benzene sulfonic acid in the CHNS module to $<0.1 \%$ for each element. The results include all combustible sulfur, both organic and inorganic, as well as all combustible carbon, organically and inorganically bound. The hydrogen content is affected by the moisture of the sample. The amount of proteins $(\% w / w)$ in the basidiocarps was calculated from the elemental nitrogen by multiplying by the factor of 3.99. This factor was offered by Fujihara et al. [32] for protein determination in mushrooms to avoid overestimation caused by the presence of interfered non-protein compounds such as urea, nucleic acids, free amino acids and chitin [33].

\subsection{Determination of Glucans}

The analytical set "MUSHROOM and YEAST $\beta$-GLUCAN" K-YBGL 07/11 (Megazyme International, Ireland) was used for the determination of total, $\alpha$ - and $\beta$-glucans [5]. The assay is based on the difference between glucose contents after the total acidic hydrolysis of glucans and specific enzymatic hydrolysis of starch-like $\alpha$-glucans. The polysaccharide fractions were solubilized in concentrated $(37 \% ; 10 \mathrm{~N})$ hydrochloric acid and then hydrolyzed by $1.3 \mathrm{~mol} \mathrm{~L}^{-1}$ hydrochloric acid at $100{ }^{\circ} \mathrm{C}$ for $2 \mathrm{~h}$; total hydrolysis was completed by incubation with a mixture of exo-(1-3)- $\beta$-glucanase and $\beta$-glucosidase. The starch-like $\alpha$-glucans were solubilized in $2 \mathrm{~mol} \mathrm{~L}^{-1}$ potassium hydroxide, and the mixture was neutralized with an excess of $1.2 \mathrm{~mol} \mathrm{~L}^{-1}$ sodium acetate buffer ( $\mathrm{pH} 3.8$ ); dissolved $\alpha$-glucans were then hydrolyzed by amyloglucosidase. The content of $\beta$-glucans (or non-starch) glucans was calculated as the difference between glucose contents after total acidic hydrolysis of glucans and specific enzymatic hydrolysis of $\alpha$-glucans. All these measurements were made in triplicate.

\subsection{Analysis of Neutral Sugars Composition}

Monosaccharide composition (neutral sugars) of the purified milled basidiocarps was determined by gas chromatography. The samples (1-2 mg) were hydrolyzed in $72 \%$ sulfuric acid and the released sugars were analyzed as alditol acetates by gas chromatography with flame-ionization detection (GC-FID) using a Shimadzu GC2010 (Shimadzu, Japan) equipped with a $30 \mathrm{~m}$ capillary column DB-225 with internal diameter of $0.25 \mathrm{~mm}$ and film thickness of $0.15 \mu \mathrm{m}$. The temperatures of injector and detector were, respectively, $220^{\circ} \mathrm{C}$ and $230^{\circ} \mathrm{C}$. The oven temperature program was as follows: $200{ }^{\circ} \mathrm{C}$ for $1 \mathrm{~min}$, then rose to $220^{\circ} \mathrm{C}\left(40^{\circ} \mathrm{C} \mathrm{min}-1\right)$, held at $220^{\circ} \mathrm{C}$ for $7 \mathrm{~min}$, then rose to $230^{\circ} \mathrm{C}\left(20^{\circ} \mathrm{C} \mathrm{min}-1\right)$, 
final temperature of $230{ }^{\circ} \mathrm{C}$ held for $1 \mathrm{~min}$; total time $9 \mathrm{~min}$. The hydrolysis of all samples was performed in duplicate.

\subsection{Vibration Spectroscopy}

Powdered basidiocarps were pressed into a pellet using hand press (Pike Technologies, Fitchburg, WI, USA). Attenuated total reflectance (ATR) FT MIR spectra (five spectra per sample, $4000-650 \mathrm{~cm}^{-1}$, 64 scans each, resolution $2 \mathrm{~cm}^{-1}$ ) of the pellets were recorded on a Nicolet 6700 FTIR spectrometer (Thermo Fisher Scientific, Waltham, MA, USA) with a KBr beam splitter and Smart MIRacle (single-reflection horizontal ATR) holder. The spectra were ATR-corrected prior to further processing. Diffuse reflectance FT NIR spectra (five spectra per sample, 10,000-4000 $\mathrm{cm}^{-1}, 100$ scans each, resolution $2 \mathrm{~cm}^{-1}$ ) of powdered dried basidiocarps were recorded on the same equipment using a $\mathrm{CaF}_{2}$ splitter and diffuse reflectance NIR smart holder. FT Raman spectra of the powder samples (three spectra per sample, $4000-150 \mathrm{~cm}^{-1}, 500 \mathrm{scans}$ each, resolution $4 \mathrm{~cm}^{-1}$ ) were recorded on a Nicolet iS50 FTIR spectrometer using a $\mathrm{CaF}_{2}$ splitter and FT Raman module (Thermo Fisher Scientific, Waltham, MA, USA). All the spectra were baseline-corrected, smoothed and normalized by scale using Omnic 8.0 software (Thermo Fisher Scientific, Waltham, MA, USA). The corrected spectra were exported in ASCII format to Origin 6.0 (OriginLab, Northampton, MA, USA) software for preparation of graphs.

\subsection{Statistical Methods}

Variance in analytical values obtained for the individual basidiocarp samples was evaluated by Tukey's honestly significant difference (HSD) test using the STATISTICA 12.0 software (StatSoft Europe, Hamburg, Germany); $p$ values of less than 0.05 were considered to indicate statistical significance. Multivariate statistical evaluation of the obtained spectroscopic data was made using TQ Analyst software (Thermo Fisher Scientific, Waltham, MA, USA) including PCA and PLSR models for two analytical values, i.e., protein and total glucan contents. The graphical outputs of both analyses included component score and calibration/cross-validation graphs. The PLSR models were created based on the first derivatives of the corrected FT MIR, FT NIR and FT Raman spectra and analytical values obtained by other analytical methods, i.e., organic elemental analysis for proteins and photometry for total glucans. The spectral regions used to calibrate a particular component were automatically selected using the TQ Analyst algorithm or were slightly modified to improve the models. Cross-validation (CV) and predicted residual error sum of squares (PRESS) diagnostics were used for evaluation of the calibration models. The former is one of the main indicators of the quality of a given model. $\mathrm{CV}$ diagnostics quantify each calibration standard as if it is a validation and calculate several parameters describing the calibration model. PRESS diagnostics show how the value of PRESS varies with the number of factors used to calibrate the components of the active model, so values given are thus an indicator of the calibration error of the PLSR models, and the optimal number of factors was chosen based on PRESS diagnostics.

\section{Results and Discussion}

\subsection{Composition of Basidiocarps}

The organic elemental composition of purified dried basidiocarps is summarized in Table 2. The carbon and hydrogen contents varied in the ranges of $\sim 39.7-41.7 \%$ and $\sim 6.7-6.8 \%$, respectively. Nitrogen $(\sim 1.6-4.4 \%)$ as well as sulfur $(\sim 0.1-0.2 \%)$ found in basidiocarps originated mainly from proteins, and nitrogen, to a lesser extent, also from chitin. The chitin- $\beta$-D-glucan complex forms the fibrillar base of fungal cell walls, and in the case of P. ostreatus basidiocarps, chitin makes up about $11.5 \%$ of the alkali-insoluble part of cell walls [29]. The protein contents calculated from elemental nitrogen were in the range of $\sim 6.2-17.5 \%$. Among the samples of basidiocarps, there are two groups of low and high protein contents; i.e., samples hk35, kryos, p80, fotios and po5 were $\sim 6.2-9.9 \%$ protein, 
and samples 3009, 3029, po4 and spoppo were $~ 14.8-17.5 \%$ protein; the rest could be assigned as medium protein content ( 11.2-13.95\%) samples.

Table 2. Composition of basidiocarps: organic elements and proteins (mean \pm SD) ${ }^{1}$.

\begin{tabular}{|c|c|c|c|c|c|}
\hline \multirow{2}{*}{ Sample } & \multicolumn{4}{|c|}{ Organic Elements $(\% w / w)$} & \multirow{2}{*}{$\begin{array}{c}\text { Proteins }^{2} \\
(\% w / w)\end{array}$} \\
\hline & $\mathbf{N}$ & $\mathrm{C}$ & $\mathbf{H}$ & $\mathrm{S}$ & \\
\hline 2013 & $3.05 \pm 0.30$ & $40.55 \pm 0.37$ & $6.69 \pm 0.09$ & $0.14 \pm 0.02$ & $12.17 \pm 1.20$ bcdef \\
\hline 2515 & $2.90 \pm 0.14$ & $40.33 \pm 0.56$ & $6.78 \pm 0.05$ & $0.14 \pm 0.02$ & $11.57 \pm 0.56$ abcde \\
\hline 3009 & $4.09 \pm 0.38$ & $41.14 \pm 0.31$ & $6.73 \pm 0.07$ & $0.19 \pm 0.04$ & $16.32 \pm 1.52$ ef \\
\hline 3029 & $4.17 \pm 0.16$ & $41.03 \pm 0.44$ & $6.79 \pm 0.09$ & $0.22 \pm 0.01$ & $16.64 \pm 0.64$ ef \\
\hline 3253 & $3.27 \pm 0.36$ & $40.83 \pm 0.44$ & $6.75 \pm 0.04$ & $0.14 \pm 0.02$ & $13.05 \pm 1.44 \mathrm{cdef}$ \\
\hline fotios & $2.13 \pm 0.22$ & $40.85 \pm 0.35$ & $6.79 \pm 0.11$ & $0.11 \pm 0.01$ & $8.50 \pm 0.88 \mathrm{abc}$ \\
\hline hk35 & $1.55 \pm 0.19$ & $39.93 \pm 0.28$ & $6.75 \pm 0.09$ & $0.09 \pm 0.02$ & $6.18 \pm 0.76 \mathrm{a}$ \\
\hline kryos & $1.56 \pm 0.20$ & $39.73 \pm 0.36$ & $6.74 \pm 0.10$ & $0.08 \pm 0.01$ & $6.22 \pm 0.80 \mathrm{a}$ \\
\hline spoppo & $3.70 \pm 0.23$ & $40.81 \pm 0.28$ & $6.80 \pm 0.05$ & $0.11 \pm 0.02$ & $14.76 \pm 0.92 \mathrm{def}$ \\
\hline po1 & $3.09 \pm 0.32$ & $40.56 \pm 0.35$ & $6.80 \pm 0.05$ & $0.14 \pm 0.01$ & $12.33 \pm 1.28$ bcdef \\
\hline po2 & $3.27 \pm 0.25$ & $40.94 \pm 0.41$ & $6.77 \pm 0.05$ & $0.17 \pm 0.02$ & $13.05 \pm 1.00 \mathrm{cdef}$ \\
\hline po3 & $3.47 \pm 0.21$ & $41.06 \pm 0.39$ & $6.78 \pm 0.07$ & $0.16 \pm 0.03$ & $13.85 \pm 0.84 \mathrm{cdef}$ \\
\hline po4 & $4.38 \pm 0.33$ & $41.73 \pm 0.40$ & $6.78 \pm 0.06$ & $0.22 \pm 0.03$ & $17.48 \pm 1.32 \mathrm{f}$ \\
\hline po5 & $2.48 \pm 0.19$ & $40.50 \pm 0.13$ & $6.79 \pm 0.08$ & $0.12 \pm 0.02$ & $9.90 \pm 0.76 \mathrm{abcd}$ \\
\hline po6 & $2.81 \pm 0.29$ & $40.88 \pm 0.36$ & $6.77 \pm 0.10$ & $0.13 \pm 0.02$ & $11.21 \pm 1.16$ abcde \\
\hline p80 & $1.73 \pm 0.17$ & $40.23 \pm 0.23$ & $6.81 \pm 0.07$ & $0.09 \pm 0.01$ & $6.90 \pm 0.68 \mathrm{ab}$ \\
\hline
\end{tabular}

${ }^{1}$ The statistical significance between mean values was calculated using ANOVA with Tukey HSD test $(p<0.05)$; $\mathrm{a}-\mathrm{f}$ are in sequence in accordance with statistically significant differences between samples. ${ }^{2} \mathrm{~N} \times 3.99$.

The neutral sugars composition of and glucan contents in purified dried basidiocarps are represented in Tables 3 and 4, respectively. Glucose predominated in all the samples and comprised $\sim 71.3-94.4 \mathrm{~mol} \%$ of all neutral sugars. It means that glucans of various structures should be the main polysaccharides of $P$. ostreatus basidiocarps. In samples 3009, 3253, p80 and spoppo, galactose, xylose, mannose and/or rhamnose were found in moderate quantities up to $~ 5.3-12.6 \mathrm{~mol} \%$ that markedly decreased the contribution of glucose to $71.3-87.5 \mathrm{~mol} \%$. These sugars originate from glycoproteins, galactans, mannogalactans or other heteropolysaccharides. In all samples, arabinose and fucose were present in much lower or even trace amounts.

Table 3. Neutral sugars composition of purified basidiocarps (mean $\pm \mathrm{SD}$ ).

\begin{tabular}{|c|c|c|c|c|c|c|c|}
\hline Sample & \multicolumn{7}{|c|}{ Neutral Sugars (mol \%) } \\
\hline 2013 & trace & $0.14 \pm 0.010$ & $2.10 \pm 0.44$ & $92.99 \pm 1.10$ & $1.46 \pm 0.19$ & $0.31 \pm 0.11$ & $3.00 \pm 0.84$ \\
\hline 2515 & $0.14 \pm 0.09$ & $0.16 \pm 0.12$ & $1.96 \pm 0.004$ & $91.20 \pm 4.27$ & $1.18 \pm 0.03$ & $0.27 \pm 0.04$ & $5.09 \pm 2.20$ \\
\hline 3009 & trace & $0.45 \pm 0.012$ & $8.70 \pm 0.25$ & $71.26 \pm 1.30$ & $12.63 \pm 0.43$ & $0.17 \pm 0.008$ & $6.78 \pm 1.98$ \\
\hline 3029 & $0.09 \pm 0.03$ & $0.24 \pm 0.08$ & $2.21 \pm 0.02$ & $93.39 \pm 1.21$ & $1.49 \pm 0.03$ & $0.24 \pm 0.05$ & $2.34 \pm 0.32$ \\
\hline hk35 & $0.29 \pm 0.22$ & $0.18 \pm 0.09$ & $2.14 \pm 0.03$ & $89.94 \pm 1.26$ & $0.56 \pm 0.04$ & $1.44 \pm 1.28$ & $5.44 \pm 0.35$ \\
\hline kryos & trace & $0.61 \pm 0.25$ & $1.85 \pm 0.07$ & $91.31 \pm 1.61$ & $0.50 \pm 0.015$ & $2.75 \pm 2.38$ & $2.94 \pm 0.94$ \\
\hline spoppo & $0.67 \pm 0.19$ & $0.49 \pm 0.09$ & $1.84 \pm 0.11$ & $87.19 \pm 1.06$ & $1.84 \pm 0.09$ & $3.08 \pm 0.19$ & $4.89 \pm 0.40$ \\
\hline po1 & $0.09 \pm 0.012$ & trace & $2.56 \pm 0.07$ & $94.41 \pm 1.21$ & $1.08 \pm 0.010$ & $0.16 \pm 0.003$ & $1.68 \pm 0.14$ \\
\hline po2 & $0.18 \pm 0.16$ & $0.13 \pm 0.05$ & $2.15 \pm 0.13$ & $94.27 \pm 1.76$ & $0.84 \pm 0.07$ & $0.34 \pm 0.005$ & $2.10 \pm 1.06$ \\
\hline po6 & $0.07 \pm 0.012$ & $0.28 \pm 0.004$ & $2.08 \pm 0.04$ & $90.54 \pm 1.54$ & $1.19 \pm 0.35$ & $0.21 \pm 0.010$ & $5.62 \pm 1.91$ \\
\hline p80 & $0.35 \pm 0.15$ & $0.09 \pm 0.019$ & $1.46 \pm 0.017$ & $86.07 \pm 2.13$ & $0.74 \pm 0.019$ & $5.29 \pm 0.93$ & $6.01 \pm 1.57$ \\
\hline
\end{tabular}

The contents of total glucans in the samples varied in the range of $\sim 18.8-58.2 \%$; the contents of $\alpha$-glucans digestible by amylolytic enzymes was low $(\sim 2.5-16.7 \%)$ in comparison with the rest of the glucans ( 15.9-51.5\%), assigned as $\beta$-glucans. The estimation of $\beta$-glucans by this test is complicated by 
the presence of (1-3)- $\alpha$-D-glucan in basidiocarps of P. ostreatus [14]. Enzymatic assay definitively gives the content of starch-like (1-4)(1-6)- $\alpha$-D-glucans, but (1-3)- $\alpha$-D-glucan, which makes up a significant part of the cell walls, is likely not cleaved by amylolytic enzymes and is therefore defined as part of the $\beta$-D-glucans. Two samples, namely kryos and po1, differed from the others in that they contained much lower total (18.8\% and 30.4\%, respectively) and $\beta$-glucans (15.9\% and $27.2 \%$, respectively). By contrast, samples po5, p80, po2 and 3009 contained maximal amounts of both total ( 55.3-58.2\%) and $\beta$-glucans $(\sim 46.7-55.4 \%)$. However, as mentioned above, only two of them, po2 and po5, contained relatively few other sugars besides glucose.

Table 4. Composition of basidiocarps: total, $\alpha$ - and $\beta$-glucans (mean $\pm \mathrm{SD}$ ).

\begin{tabular}{cccc}
\hline \multirow{2}{*}{ Sample } & \multicolumn{3}{c}{ Glucans $(\% \boldsymbol{w} / \boldsymbol{w})^{\mathbf{1}}$} \\
\cline { 2 - 4 } & Total & $\boldsymbol{\alpha}$-Glucans & $\beta$-Glucans \\
\hline 2013 & $48.44 \pm 2.01 \mathrm{c}$ & $8.98 \pm 0.27 \mathrm{~cd}$ & $39.46 \pm 1.61 \mathrm{bcde}$ \\
2515 & $45.99 \pm 1.13 \mathrm{c}$ & $13.85 \pm 0.14 \mathrm{e}$ & $32.14 \pm 0.82 \mathrm{bc}$ \\
3009 & $55.31 \pm 1.56 \mathrm{c}$ & $8.66 \pm 0.17 \mathrm{c}$ & $46.65 \pm 1.35 \mathrm{def}$ \\
3029 & $43.54 \pm 2.80 \mathrm{bc}$ & $4.89 \pm 0.52 \mathrm{ab}$ & $38.79 \pm 1.97 \mathrm{bcde}$ \\
3253 & $52.51 \pm 1.44 \mathrm{c}$ & $11.42 \pm 0.30 \mathrm{cde}$ & $41.10 \pm 3.06 \mathrm{cdef}$ \\
fotios & $45.45 \pm 2.30 \mathrm{bc}$ & $5.45 \pm 0.43 \mathrm{~b}$ & $40.03 \pm 1.96 \mathrm{bcde}$ \\
hk35 & $49.22 \pm 2.55 \mathrm{c}$ & $5.22 \pm 0.61 \mathrm{ab}$ & $44.00 \pm 1.75 \mathrm{cdef}$ \\
kryos & $18.79 \pm 3.39 \mathrm{a}$ & $2.94 \pm 0.46 \mathrm{ab}$ & $15.85 \pm 2.51 \mathrm{a}$ \\
spoppo & $50.58 \pm 2.85 \mathrm{c}$ & $11.76 \pm 0.93 \mathrm{de}$ & $38.86 \pm 2.29 \mathrm{bcde}$ \\
po1 & $30.39 \pm 2.95 \mathrm{ab}$ & $3.15 \pm 0.25 \mathrm{ab}$ & $27.23 \pm 2.25 \mathrm{ab}$ \\
po2 & $56.17 \pm 2.79 \mathrm{c}$ & $4.63 \pm 0.81 \mathrm{ab}$ & $51.54 \pm 1.80 \mathrm{ef}$ \\
po3 & $48.32 \pm 3.22 \mathrm{c}$ & $9.03 \pm 0.14 \mathrm{~cd}$ & $39.29 \pm 2.77 \mathrm{bcde}$ \\
po4 & $45.98 \pm 2.08 \mathrm{c}$ & $12.43 \pm 0.30 \mathrm{e}$ & $33.56 \pm 1.57 \mathrm{bcd}$ \\
po5 & $58.17 \pm 3.14 \mathrm{c}$ & $9.55 \pm 0.68 \mathrm{~cd}$ & $48.62 \pm 1.80 \mathrm{ef}$ \\
po6 & $50.84 \pm 3.39 \mathrm{c}$ & $16.72 \pm 0.48 \mathrm{f}$ & $34.12 \pm 2.37 \mathrm{bcd}$ \\
p80 & $57.89 \pm 2.60 \mathrm{c}$ & $2.52 \pm 0.19 \mathrm{a}$ & $55.36 \pm 2.33 \mathrm{f}$ \\
\hline
\end{tabular}

${ }^{1}$ The statistical significance between mean values was calculated using ANOVA with Tukey HSD test $(p<0.05)$; $\mathrm{a}-\mathrm{f}$ are in sequence in accordance with statistically significant differences between samples.

\subsection{Vibration Spectroscopy}

\subsubsection{FT MIR}

The average normalized FT MIR spectra of purified basidiocarps are represented in Figure 1a. The intense highly overlapped bands at $1200-950 \mathrm{~cm}^{-1}$, which were assigned mainly to C-C and C-O stretching vibrations in pyranoid rings, are characteristic for polysaccharides [34]. Among these bands, the band near $1150 \mathrm{~cm}^{-1}$ was found for all samples and assigned to the $\mathrm{C}-\mathrm{O}-\mathrm{C}$ stretching vibration of glycosidic bonds. The envelope shape of this region is characteristic for the mixture of fungal cell wall polysaccharides, mainly branched (1-3)(1-6)- $\beta$-D-glucan, linear (1-3)- $\alpha$-D-glucan and chitin; the IR bands or shoulders near 1375, 1316, 1253, 1202, 1150, 1071-1076 and 1033-1040 $\mathrm{cm}^{-1}$ found for all samples are characteristic for fungal $\beta$-D-glucans $[5,14,26]$. In addition, the broad and weak IR band near $897 \mathrm{~cm}^{-1}$ arose from $\mathrm{C} 1 \mathrm{H}$ bending in $\beta$-anomeric sugar units of chitin and $\beta$-D-glucan $[14,35,36]$. By contrast, the weak bands at 930 and $847-853 \mathrm{~cm}^{-1}$ indicated the presence of $\alpha$-D-glucans [36-38]. Liu et al. [39] identified individual glucans in basidiocarps of Boletus mushrooms by characteristic IR bands at 1155, 1025, 930 and $850 \mathrm{~cm}^{-1}$ ( $\alpha$-glucans) and at 1160, 1078, 1041 and $890 \mathrm{~cm}^{-1}$ ( $\beta$-glucans).

Two IR bands at $1632-1650 \mathrm{~cm}^{-1}$ (amide I) and $1554-1535 \mathrm{~cm}^{-1}$ (amide II) were assigned to amide vibrations of chitin and proteins [40,41]. The former band is overlapped by that of water in-plane deformation near $1640 \mathrm{~cm}^{-1}$. For high-protein samples (po4, 3029), the amide II band was found near $1535 \mathrm{~cm}^{-1}$, while in the case of some samples containing less protein (kryos, hk35 and p80), there was another band near 1550-1554 $\mathrm{cm}^{-1}$ attributed to $\alpha$-chitin. Intensities of these amide bands highly varied for the samples and increased with the protein content. Similarly, the intensity of another band near $1236 \mathrm{~cm}^{-1}$ was more pronounced for samples rich in protein (po4, 3009 and 3029), but was only 
a shoulder of the band at $1253 \mathrm{~cm}^{-1}$ for the low-protein samples (kryos, hk35 and p80). Therefore, the band near $1236 \mathrm{~cm}^{-1}$ was assigned to the amide III vibration of proteins [41]. All the spectra also showed a shoulder at $1726 \mathrm{~cm}^{-1}$ assigned to the $\mathrm{C}=\mathrm{O}$ stretching vibrations of carboxylic groups [42].
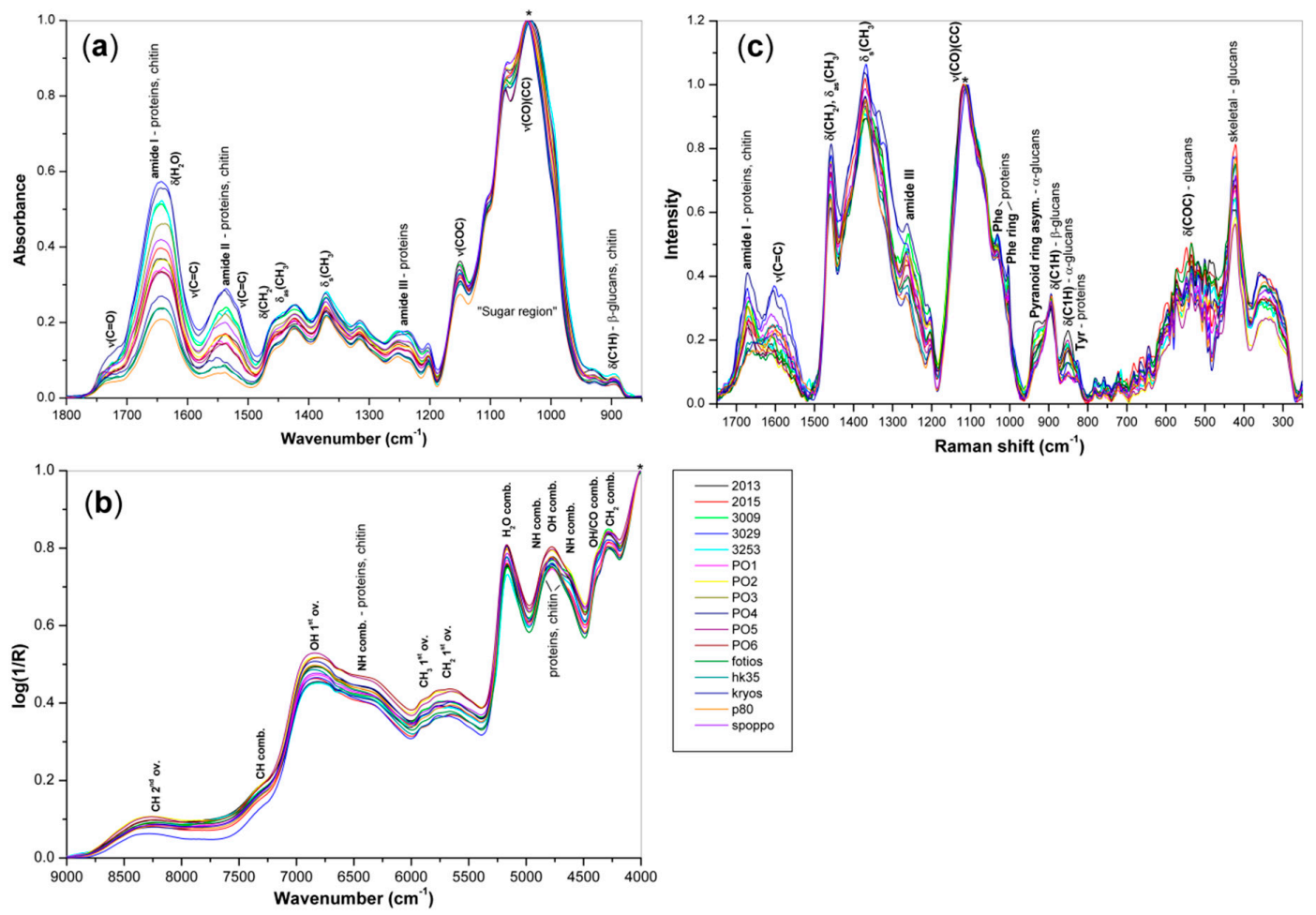

Figure 1. Average normalized spectra of sixteen P. ostreatus basidiocarp samples: (a) Fourier-transformed (FT) mid-infrared (FT MIR), (b) FT near-infrared (NIR) and (c) FT Raman. The asterisk indicates the peak used to normalize the spectra.

\subsubsection{FT NIR}

The average normalized FT NIR spectra of purified basidiocarps are represented in Figure $1 \mathrm{~b}$. The spectra of protein-rich samples demonstrated two shoulders at $4860 \mathrm{~cm}^{-1}$ (amide A/II) and $4610 \mathrm{~cm}^{-1}$ (amide B/II) assigned to the combinations of NH stretching and bending modes characteristic for proteins [43-45]. Other protein bands were found near $6600 \mathrm{~cm}^{-1}$ (amide A + 1st overtone of amide I), $6471 \mathrm{~cm}^{-1}$ (1st overtone of amide A) and $6330 \mathrm{~cm}^{-1}$ (amide A + 1st overtone of amide II). The bands of polysaccharide vibrations were found near $4300 \mathrm{~cm}^{-1}\left(\mathrm{CH}_{2}\right.$ stretch/bend combination), $4400 \mathrm{~cm}^{-1}$ (OH/CO stretch combination), 4770-4790 cm $\mathrm{cm}^{-1}$ (OH stretch/bend combination), $6310 \mathrm{~cm}^{-1}$ ( $\mathrm{CH}$ stretch 1 st overtone) and $6980 \mathrm{~cm}^{-1}(\mathrm{OH}$ stretch 1 st overtone) $[46,47]$. Polysaccharides and proteins contributed to the regions of $4400-5000 \mathrm{~cm}^{-1}\left(\mathrm{CH}, \mathrm{OH}\right.$ and $\mathrm{NH}$ stretch/bend combinations) and $5400-6000 \mathrm{~cm}^{-1}$ $\left(\mathrm{CH}_{2}\right.$ and $\mathrm{CH}_{3}$ stretch 1st overtones) in a different manner.

\subsubsection{FT Raman}

The average normalized FT Raman spectra of purified basidiocarps are represented in Figure 1c. Bands at 1455-1461 and 1367-1374 $\mathrm{cm}^{-1}$ were assigned to bending vibrations of $\mathrm{CH}_{2}$ and $\mathrm{CH}_{3}$ groups in proteins and polysaccharides [34,48]. Intense bands at $1106-1120 \mathrm{~cm}^{-1}$ arose mainly from the $\mathrm{C}-\mathrm{O}$ and $C-C$ stretching vibrations of polysaccharides. The sharp band at $894 \mathrm{~cm}^{-1}$ indicated the $\beta$-anomeric configuration of monosaccharide units in $\beta$-D-glucans and chitin, while bands near 930 and $850 \mathrm{~cm}^{-1}$ were characteristic for $\alpha$-anomeric configuration in $\alpha$-D-glucans [14,26]. However, the tyrosine doublet bands near 830 and $850 \mathrm{~cm}^{-1}$ overlapped the latter band of $\alpha$-glucans [48,49]. The band at $420-428 \mathrm{~cm}^{-1}$ was assigned to skeletal vibrations of polysaccharides, so it could be used as non-specific marker of glucans [49]. The bands near $1670 \mathrm{~cm}^{-1}$ (amide I) and at $1260-1267 \mathrm{~cm}^{-1}$ (amide III) indicated the 
presence of proteins [48]. In addition, two bands near 1130 and $1004 \mathrm{~cm}^{-1}$ were assigned to vibrations of phenylalanine moieties; the latter band is often used as a reference for proteins. The broad band centered near $1604 \mathrm{~cm}^{-1}(\mathrm{C}=\mathrm{C}$ stretching) indicated unsaturated and aromatic compounds, which were still present in some samples.

\subsection{PCA of Spectroscopic Data}

The PCA was performed on the FT MIR, FT NIR and FT Raman spectra of the P. ostreatus basidiocarps to detect clusters according to the protein and total glucan contents. Three main principal components, PC1, PC2 and PC3, explaining 70-86\% of the variance $(\sim 49-51 \%$ for PC1, $19-30 \%$ for PC2 and $\sim 8-15 \%$ for PC3) were used for the discrimination of basidiocarp samples. Unfortunately, none of these principal components or their pairs gave an unambiguous separation of the samples in accordance with their composition. So, we had to use all three components together in 3D to visualize the discrimination of the samples. In the case of FT MIR, and especially FT NIR, the use of the first derivative gave better discrimination results in comparison with the spectra themselves that could be explained by the leveling out of the background effects.

\subsubsection{PCA Loadings}

The PCA loadings of first three PCs for the FT MIR, FT NIR and FT Raman methods are represented in Figure 2; the band assignment is summarized in Table 5. In the case of FT MIR (Figure 2a), PC1 and PC2 showed two similar intense negative-to-positive couplets at $1697-1619 \mathrm{~cm}^{-1}$ and $1559-1511 \mathrm{~cm}^{-1}$ and a negative peak at $1246-1242 \mathrm{~cm}^{-1}$ corresponding to the amide I, amide II and amide III vibrations, respectively $[40,41]$. By contrast, PC3 showed two negative-to-positive couplets in this region at $1633-1614 \mathrm{~cm}^{-1}$ and $1564-1503 \mathrm{~cm}^{-1}$. These PCs also showed several intense peaks in the region of carbohydrate vibrations of $1204-943 \mathrm{~cm}^{-1}$, so they are sensitive to the amount and composition of polysaccharides [34].
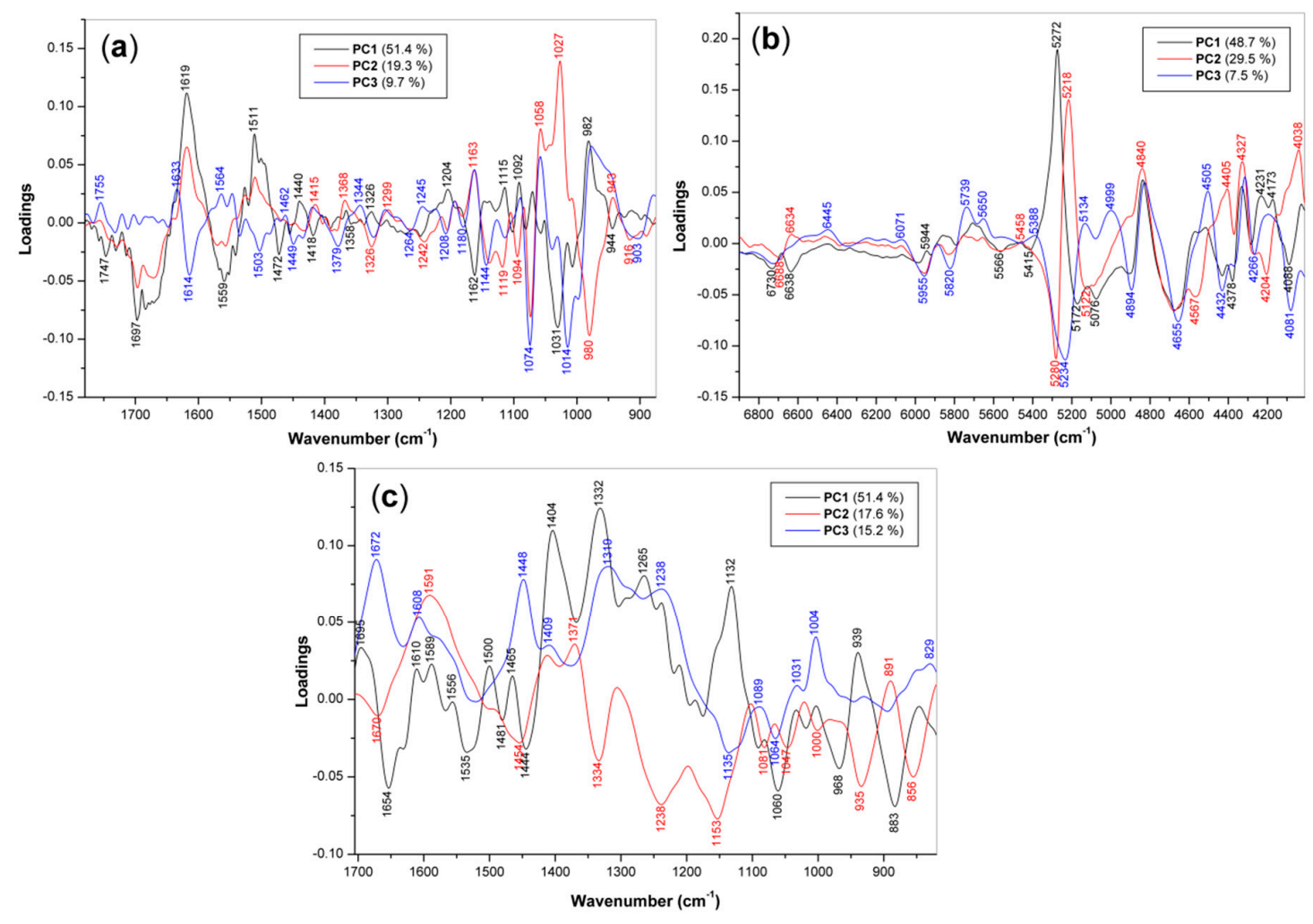

Figure 2. PCA loadings of the first three PCs for the spectroscopic data: (a) FT MIR, (b) FT NIR and (c) FT Raman. 
Table 5. Assignments of loading bands $\left(\mathrm{cm}^{-1}\right)$ for principal components (PC) 1-3.

\begin{tabular}{|c|c|c|c|c|c|}
\hline \multirow{3}{*}{ Method } & \multicolumn{4}{|c|}{ Wavenumber $\left(\mathrm{cm}^{-1}\right)$} & \multirow{3}{*}{ Origin $^{1}$} \\
\hline & \multicolumn{3}{|c|}{ Loadings } & \multirow{2}{*}{ Spectra } & \\
\hline & PC1 & PC2 & PC3 & & \\
\hline \multirow{13}{*}{ FT MIR } & $\downarrow 1697 / \uparrow 1619$ & $\downarrow 1697 / \uparrow 1619$ & $\uparrow 1633 / \downarrow 1614$ & 1642 & amide I—proteins, chitin \\
\hline & $\downarrow 1559 / \uparrow 1511$ & $\downarrow 1556 / \uparrow 1511$ & $\uparrow 1564 / \downarrow 1503$ & 1536 & amide II-proteins, chitin \\
\hline & $\downarrow 1472 / \uparrow 1440$ & & $\uparrow 1462 / \downarrow 1449$ & $1455 \mathrm{sh}$ & $\delta\left(\mathrm{CH}_{2}\right), \delta_{\mathrm{as}}\left(\mathrm{CH}_{3}\right)$ \\
\hline & $\downarrow 1418$ & $\uparrow 1415$ & $\uparrow 1418$ & 1421 & $\delta(\mathrm{CHO})(\mathrm{COH})$-glucans \\
\hline & & $\downarrow 1382 / \uparrow 1368$ & $\downarrow 1379$ & 1375 & $\delta_{\mathrm{s}}\left(\mathrm{CH}_{3}\right)$ - proteins, chitin \\
\hline & $\uparrow 1326$ & $\downarrow 1326 / \uparrow 1299$ & $\downarrow 1324 / \uparrow 1300$ & 1316 & amide III—chitin \\
\hline & $\downarrow 1246$ & $\downarrow 1242$ & $\uparrow 1245$ & 1236 & amide III—proteins \\
\hline & $\uparrow 1204$ & $\downarrow 1206$ & $\downarrow 1208$ & 1202 & $\beta$-D-glucans \\
\hline & $\downarrow 1162 / \uparrow 1144$ & $\uparrow 1163 / \downarrow 1142$ & $\uparrow 1163 / \downarrow 1144$ & 1150 & $v(\mathrm{COC})$-glucans, chitin \\
\hline & $\uparrow 1115$ & $\downarrow 1119$ & $\downarrow 1114$ & 1100 & $v(\mathrm{CO})(\mathrm{CC})$-glucans, chitin \\
\hline & $\uparrow 1070$ & $\downarrow 1074 / \uparrow 1058$ & $\downarrow 1074 / \uparrow 1058$ & 1075 & $v(\mathrm{CO})(\mathrm{CC})$ - glucans, chitin \\
\hline & $\downarrow 1031 / \uparrow 982$ & $\uparrow 1027 / \downarrow 980$ & $\downarrow 1014 / \uparrow 980$ & 1040 & $v(\mathrm{CO})(\mathrm{CC})$ - glucans, chitin \\
\hline & $\downarrow 944$ & $\uparrow 943$ & $\uparrow 946$ & 930 & $\alpha$-D-glucans \\
\hline \multirow{11}{*}{ FT NIR } & $\downarrow 6730, \downarrow 6638$ & $\downarrow 6688 / \uparrow 6634$ & $\downarrow 6700$ & 6600sh & $\mathrm{NH}$ comb.-proteins, chitin \\
\hline & & & $\uparrow 6445$ & $6470 \mathrm{sh}$ & $\mathrm{NH} 1^{\text {st }}$ ov.-proteins, chitin \\
\hline & & $\downarrow 5955, \downarrow 5820$ & $\downarrow 5955, \downarrow 5820$ & & $\mathrm{CH}, \mathrm{CH}_{2}, \mathrm{CH}_{3}$ 1st ov. \\
\hline & & & $\uparrow 5739, \uparrow 5850$ & & $\mathrm{CH}, \mathrm{CH}_{2}, \mathrm{CH}_{3}$ 1st ov. \\
\hline & $\uparrow 5272 / \downarrow 5172$ & $\downarrow 5280 / \uparrow 5218$ & $\downarrow 5234$ & 5165 & OH comb.-glucans, chitin \\
\hline & $\downarrow 5076$ & $\downarrow 5122$ & $\downarrow 5134, \downarrow 4999$ & & OH comb.-glucans, chitin \\
\hline & $\downarrow 4894 / \uparrow 4840$ & $\uparrow 4900, \uparrow 4840$ & $\downarrow 4894 / \uparrow 4840$ & & amide $\mathrm{A} / \mathrm{II}$ comb.-proteins \\
\hline & $\downarrow 4675 / \uparrow 4515$ & $\downarrow 4675, \downarrow 4567$ & $\downarrow 4655 / \uparrow 4505$ & & amide B/II comb.-proteins \\
\hline & $\downarrow 4432, \downarrow 4378$ & $\uparrow 4405$ & $\downarrow 4432$ & & $\mathrm{OH} / \mathrm{CO}$ comb.-glucans, chitin \\
\hline & $\uparrow 4231$ & $\uparrow 4327 / \downarrow 4266$ & $\uparrow 4335 / \downarrow 4266$ & 4285 & $\mathrm{CH}, \mathrm{CH}_{2}, \mathrm{CH}_{3}$ comb. \\
\hline & $\uparrow 4173 / \downarrow 4088$ & $\downarrow 4204 / 4038$ & $\uparrow 4150 / \downarrow 4081$ & & $\mathrm{CH}, \mathrm{CH}_{2}, \mathrm{CH}_{3}$ comb. \\
\hline \multirow{16}{*}{ FT Raman } & $\downarrow 1654$ & $\downarrow 1670$ & $\uparrow 1672$ & 1670 & amide I-proteins, chitin \\
\hline & $\uparrow 1610, \uparrow 1589$ & $\uparrow 1591$ & $\uparrow 1608$ & 1604 & $v_{\text {as }}\left(\mathrm{COO}^{-}\right)$-proteins \\
\hline & $\downarrow 1535$ & & & & $v(\mathrm{C}=\mathrm{C})$-phenolic compounds \\
\hline & $\downarrow 1444$ & $\downarrow 1454$ & $\uparrow 1448$ & 1457 & $\delta\left(\mathrm{CH}_{2}\right), \delta_{\mathrm{as}}\left(\mathrm{CH}_{3}\right)$ \\
\hline & $\uparrow 1404$ & $\uparrow 1409$ & $\uparrow 1409$ & & $v_{\mathrm{s}}\left(\mathrm{COO}^{-}\right)$-proteins \\
\hline & & $\uparrow 1371$ & & & $\delta_{\mathrm{s}}\left(\mathrm{CH}_{3}\right)$-proteins, chitin \\
\hline & $\uparrow 1332$ & $\downarrow 1334$ & $\uparrow 1310$ & 1335 & $\delta(\mathrm{CH}), \delta(\mathrm{OH})$ \\
\hline & $\uparrow 1265$ & $\downarrow 1238$ & $\uparrow 1238$ & 1263 & amide III-proteins \\
\hline & $\uparrow 1132$ & $\downarrow 1153$ & $\downarrow 1135$ & 1116 & $v(\mathrm{CO})(\mathrm{CC})$-glucans, chitin \\
\hline & $\downarrow 1060$ & $\downarrow 1081,1047$ & $\downarrow 1064$ & & $v(\mathrm{CO})(\mathrm{CC})$-glucans, chitin \\
\hline & & $\downarrow 1000$ & $\uparrow 1031$ & 1033 & Phe ring-proteins \\
\hline & & & $\uparrow 1004$ & 1004 & Phe ring-proteins \\
\hline & $\downarrow 968, \uparrow 939$ & $\downarrow 935$ & & & $\alpha$-D-glucans \\
\hline & $\downarrow 883$ & $\uparrow 891$ & & 894 & $\delta(\mathrm{C} 1 \mathrm{H})-\beta$-D-glucans, chitin \\
\hline & & $\downarrow 856$ & & & $\delta(\mathrm{C} 1 \mathrm{H})-\alpha$-D-glucans \\
\hline & & & $\uparrow 845, \uparrow 829$ & & Tyr ring-proteins \\
\hline
\end{tabular}

In the case of PCA loadings for FT NIR (Figure 2b), the most intense peaks were found at 5300-5200 $\mathrm{cm}^{-1}$ assigned to the combination of $\mathrm{OH}$ stretching and bend vibrations of polysaccharides [46,47]. Two negative peaks at 4432 and $4378 \mathrm{~cm}^{-1}$ (PC1, PC3) and a positive peak at $4405 \mathrm{~cm}^{-1}$ (PC2) originated from the $\mathrm{OH} / \mathrm{CO}$ stretch combination of polysaccharides. The negative-to-positive couplets (at $4894-4840 \mathrm{~cm}^{-1}$ and $4675-4505 \mathrm{~cm}^{-1}$ were found in PC1 and PC3 loadings. In the case of PC2, four peaks were found in these regions: two positive ones at 4900 and $4840 \mathrm{~cm}^{-1}$ and two negative ones at 4675 and $4567 \mathrm{~cm}^{-1}$. All these peaks originated from amide combination bands of proteins [43-45]. In addition, for all three PCs, weak peaks at $6730-6445 \mathrm{~cm}^{-1}$ also arose from protein vibrations. Finally, the intense negative and positive peaks in the $\mathrm{CH}$ combinations and overtones at $6000-5600 \mathrm{~cm}^{-1}$ and $4300-4000 \mathrm{~cm}^{-1}$ had contributions from both proteins and polysaccharides.

The assignment of the PC1-3 loadings for FT Raman spectra (Figure 2c) is difficult because many peaks originated from the $\mathrm{C}-\mathrm{H}$ and $\mathrm{C}-\mathrm{C}$ vibrations of both proteins and glucans [34,48]. However, it is evident for PC1 and PC2 that the positive and negative peaks at $970-850 \mathrm{~cm}^{-1}$ arose from anomeric sensitive vibrations of chitin, $\alpha$ - and $\beta$-D-glucans $[14,26]$, so these PCs could be useful for distinguishing of basidiocarps based on polysaccharide composition. On the other hand, PC3 loadings demonstrate several positive peaks at $1672 \mathrm{~cm}^{-1}$ (amide I), 1608 and $1409 \mathrm{~cm}^{-1}$ (COO- stretching in Asp and Glu), 
$1238 \mathrm{~cm}^{-1}$ (amide III), 1031 and $1004 \mathrm{~cm}^{-1}$ (Phe ring vibrations) and 850 and $829 \mathrm{~cm}^{-1}$ (Tyr doublet); all of them are characteristic for proteins $[48,49]$.

\subsubsection{D Component Score}

The 3D component score graphs of PC1 versus PC2 versus PC3 for the 1st derivations of FT MIR spectra (1780-875 $\left.\mathrm{cm}^{-1}\right)$, 1st derivations of FT NIR spectra $\left(6900-4000 \mathrm{~cm}^{-1}\right)$ and normalized FT Raman spectra $\left(1705-825 \mathrm{~cm}^{-1}\right)$ are represented in Figure 3. These graphs illustrate discrimination of the basidiocarp samples originating from sixteen P. ostreatus strains. The samples were assigned according to the amount of proteins and glucans, i.e., with low, medium and high contents of these components. It is evident from all these graphs that the samples po4, 3009 and 3029 with high protein contents ( 16.6-17.5\%) as well as kryos, hk35, p80 and fotios with low protein contents ( 6.2-8.5\%) were more or less separated from the rest. Samples spoppo and po3, which contained $\sim 14.8$ and $\sim 13.9 \%$ proteins, respectively, were located in close proximity to the clusters of high- and medium-protein samples. Unfortunately, there was no discrimination of the basidiocarp samples based on the content of total glucans, although in some cases it was possible to localize samples with a high content (po5 and po2) or, on the contrary, a low content (kryos and po1) of these polysaccharides.

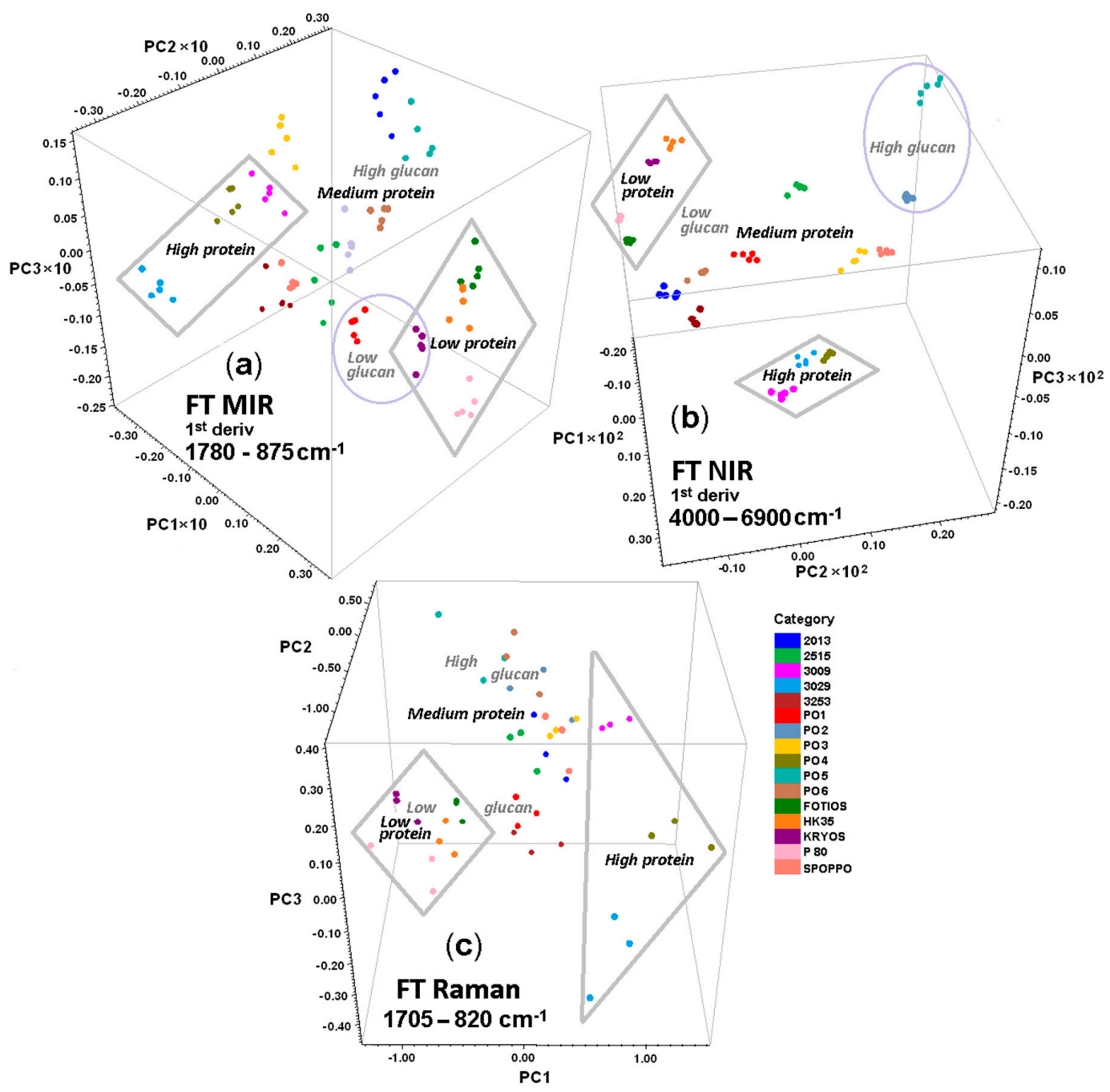

Figure 3. The 3D score plots of PC1 versus PC2 versus PC3 for the PCA of spectroscopic data: (a) FT MIR, (b) FT NIR and (c) FT Raman. 
Difficulties in distinguishing basidiocarp samples based on total glucan content can be explained by the fact that the amount of total glucans determined by the enzymatic set includes polysaccharides, which, along with the difference between $\alpha$ - and $\beta$-anomeric polymers, also differ in glycosidic bond configuration and branching $[14,26,50]$. Oyster mushrooms contain a number of water-soluble homoand heterogalactans, first of all branched mannogalactans that contribute to polysaccharide vibration bands [51]. For example, in a 3D score plot for FT Raman spectra (Figure 3c), the points of sample 3009, which contained a significant proportion of mannose and galactose in the monosaccharide composition, were displaced from the clusters of the other two high-protein samples, 3029 and po4, that may be associated not only with the higher glucan content, but also with the contribution of mannogalactan. The effect of fungal chitin, which is structurally similar to fungal $\beta$-D-glucans, should also be taken into account [29]. Moreover, the presence of chitin in the basidiocarp also influences the sample discrimination by protein content using PCA of vibration spectroscopic data, since both biopolymers contain amide groups that contribute to the spectra in a similar way.

\subsection{PLSR Models for Protein and Total Glucan Contents}

The PLSR models based on the FT MIR, FT NIR and FT Raman data were developed for the prediction of the protein and total glucan contents in the basidiocarps of P. ostreatus mushrooms. The obtained correlation and cross-validation plots are represented in Figure 4. The parameters of all calibration models, including number of factors and spectral regions, are summarized in Table 6 . The regression coefficients $R^{2}$ and the root mean square errors (RMSE) for the calibration $\left(R_{\text {cal }}^{2}, \mathrm{RMSE}_{\mathrm{cal}}\right)$ were in the range of $0.908-0.996$ and $0.269-2.98$, respectively.

Table 6. Parameters of the partial least squares regression (PLSR) models.

\begin{tabular}{|c|c|c|c|c|c|c|}
\hline \multirow{2}{*}{ Parameters } & \multicolumn{3}{|c|}{ Proteins } & \multicolumn{3}{|c|}{ Total Glucans } \\
\hline & FT MIR & FT NIR & FT Raman & FT MIR & FT NIR & FT Raman \\
\hline $\begin{array}{c}\text { Spectroscopic } \\
\text { data }\end{array}$ & 1st deriv. & 1st deriv. & spectra & 1st deriv. & 1st deriv. & spectra \\
\hline $\begin{array}{l}\text { Region } \\
\left(\mathrm{cm}^{-1}\right)\end{array}$ & $1800-845$ & $\begin{array}{l}6800-6550 \\
5150-4000\end{array}$ & $1735-220$ & $1800-845$ & $\begin{array}{l}6800-6550 \\
5150-4000\end{array}$ & $1555-380$ \\
\hline $\begin{array}{c}\text { Number of } \\
\text { factors }\end{array}$ & 10 & 5 & 5 & 7 & 12 & 8 \\
\hline$R_{\mathrm{cal}}^{2}$ & 0.994 & 0.994 & 0.981 & 0.908 & 0.996 & 0.984 \\
\hline$R_{\mathrm{cV}}^{2}$ & 0.910 & 0.970 & 0.901 & 0.370 & 0.804 & 0.599 \\
\hline $\mathrm{RMSE}_{\mathrm{cal}}$ & 0.269 & 0.275 & 0.485 & 2.98 & 0.612 & 1.24 \\
\hline $\mathrm{RMSE}_{\mathrm{cv}}$ & 1.08 & 0.608 & 1.11 & 8.50 & 4.66 & 6.61 \\
\hline
\end{tabular}

${ }^{1}$ According to predicted residual error sum of squares (PRESS) diagnosis.

Among the vibration spectroscopic methods used, the FT NIR regression models for both protein and total glucans gave the best calibration and cross-validation parameters. Unfortunately, in all cases, the cross-validation of PLSR models for total glucans showed worse results than for proteins, and no suitable RMSE models separately for $\alpha$ - and $\beta$-glucans were obtained at all. Indeed, for proteins, the cross-validation parameters $R^{2}$ cv and $\mathrm{RMSE}_{\mathrm{cal}}$ were in the range of $0.901-0.970$ and $0.608-1.11$, respectively. These values are acceptable for PLSR models. By contrast, the corresponding values for total glucans significantly differed and were in the range of $0.370-0.804$ and $4.66-8.50$.

Suitable PLSR models based on mean normalized FT MIR ATR spectra have already been successfully developed to predict total and $\beta$-glucans in oyster mushroom basidiocarps [27], but in this case, a larger set of 72 samples was used, including seven for external validation. Perhaps increasing the number of samples could improve the determination of glucans by vibration spectroscopic methods, and another way to normalize the spectra could also help. By normalizing the working spectral regions by the most intense peak, which in all cases had a large contribution from the vibrations of glucans and polysaccharides in general, it was possible to clearly distinguish the spectral differences associated 
with the amount of proteins, while the difference in the glucan content was leveled. This may have led to deterioration in predicting total glucans compared to proteins.
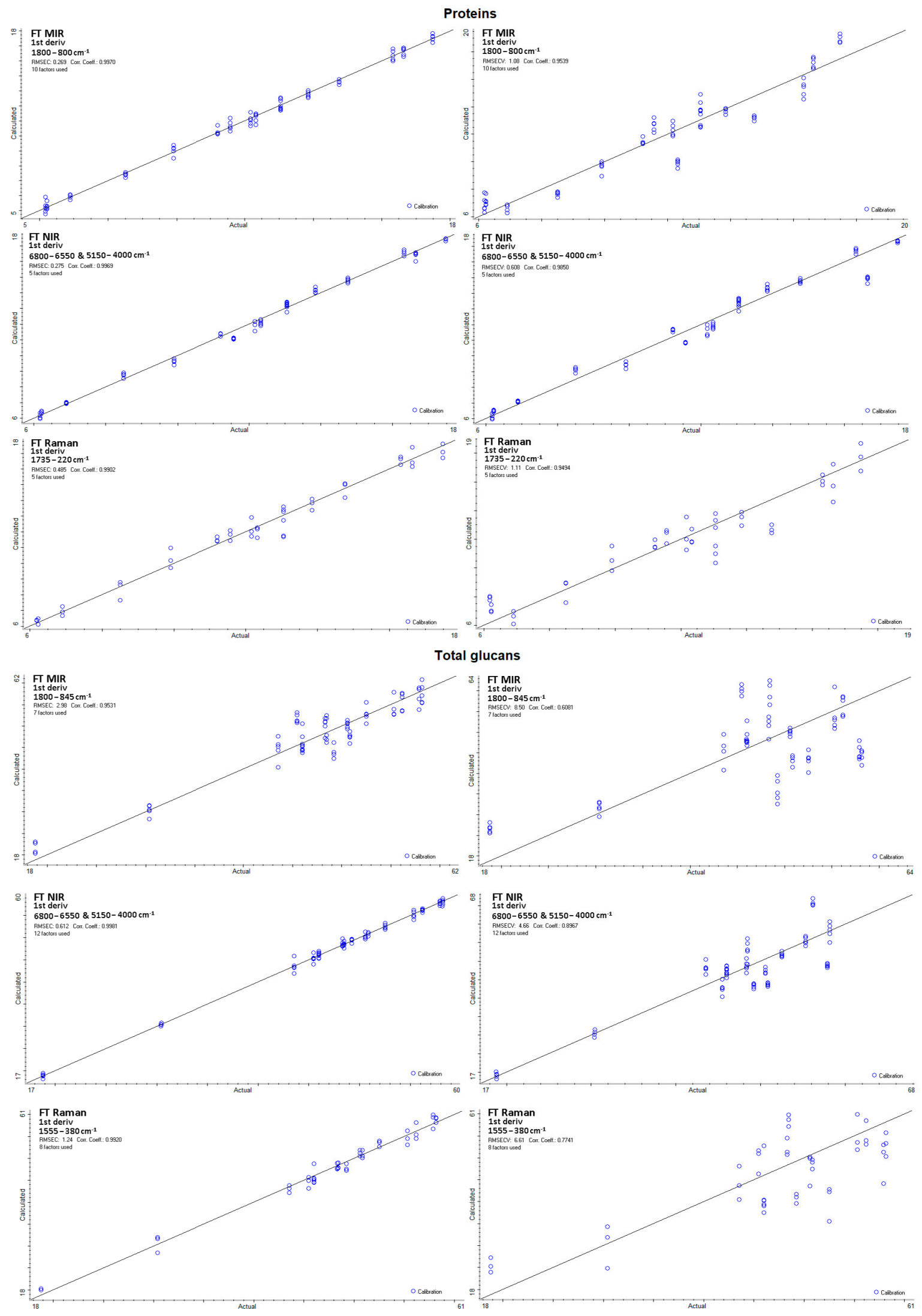

Figure 4. The PLSR models for the protein and total glucan contents in P. ostreatus basidiocarps. 


\subsection{Estimation of Proteins By Raman Band at $1004 \mathrm{~cm}^{-1}$}

As it was mentioned above, the Raman band of Phe ring vibration at $1004 \mathrm{~cm}^{-1}$ is characteristic for proteins. The relative height of this narrow band was used for quantification of proteins in P. ostreatus basidiocarps. The baseline at 1025-990 $\mathrm{cm}^{-1}$ was used for the estimation of the height (Figure 5a). The strong correlation between this height and protein content was found (Figure $5 b$ ), so this value can be used for quantification of proteins in P. ostreatus basidiocarps. On the other hand, if we take into account that the selected band refers exclusively to the specific vibration of proteins, then this strong correlation also confirms that the nitrogen content is indeed suitable for determining the protein, and the presence of chitin does not significantly affect this assessment.
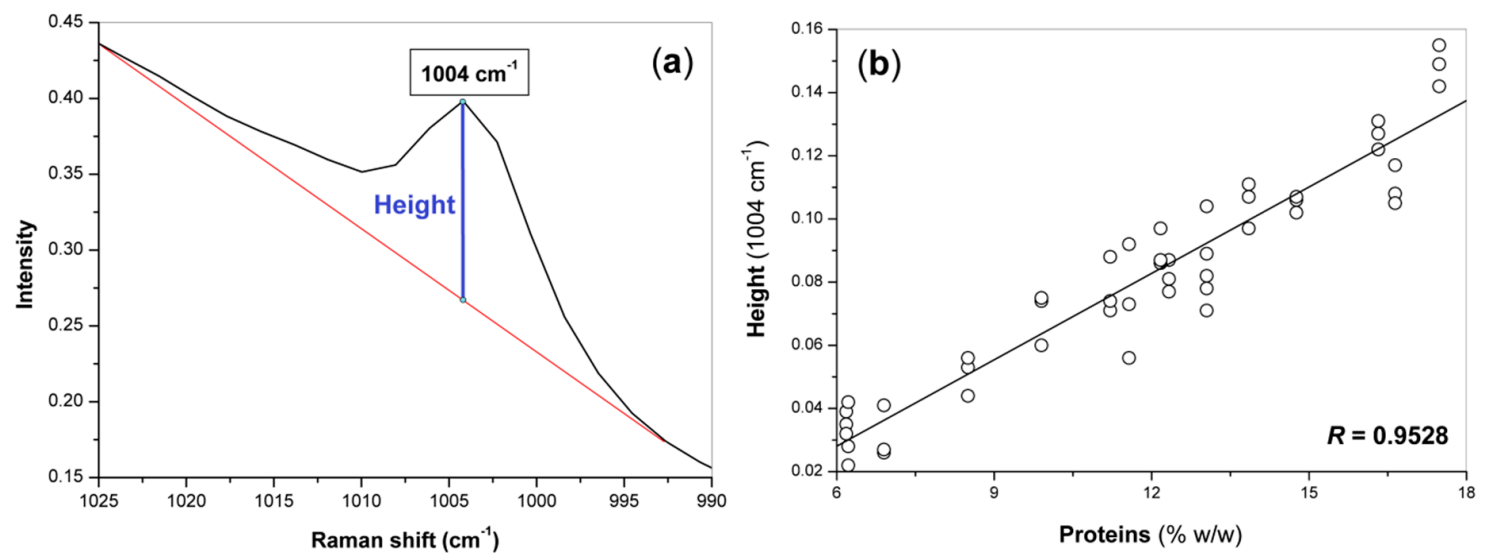

Figure 5. Using the Raman band of the Phe ring breathing vibration at $1004 \mathrm{~cm}^{-1}$ for determination of proteins in P. ostreatus basidiocarps: (a) measuring of the height; (b) correlation between this height and protein content $(\% w / w)$.

\section{Conclusions}

Analytical results confirmed significant differences in the biopolymer composition of oyster mushroom basidiocarps. In the vibrational spectra of basidiocarp samples, characteristic bands of proteins and polysaccharides were found that make it possible to evaluate individual strains by their biopolymer composition, and therefore can be used to assess the quality of mushrooms as culinary ingredients and also as the source for preparation of food supplements.

The combination of vibrational spectroscopy and chemometrics proved to be successful in discriminating basidiocarp samples based on protein contribution and, to a lesser extent, total glucans. The results obtained can be considered as an example of screening of individual oyster mushroom strains, the criterion of which is the choice of forms for the purpose of their selective cultivation and further use. Obviously, high protein content is preferable for culinary purposes, while the presence of $\beta$-D-glucans can have dietary and even medicinal significance.

A combination of the above methods has also been proposed to predict the biopolymer contents of basidiocarps. Again, the models for predicting proteins were found to be more precise and accurate than the corresponding models for total glucan. Thus, despite the high content of polysaccharides in basidiocarps compared to proteins, multivariate analysis of vibrational spectra was more effective in relation to proteins than total glucans. The difficulties associated with spectroscopic assessment and quantification of the total amount of glucans in basidiocarp can be explained by the wide structural diversity of these polysaccharides in oyster mushrooms. In addition, the spectral contribution of other polysaccharides, namely mannogalactan and chitin, may be responsible for the poorer results for total glucans. Further research is required to better evaluate and distinguish the basidiocarps of different strains in terms of their polysaccharide composition.

Despite these difficulties, the result of this study shows that the combination of vibration spectroscopy with multivariate statistical methods can serve as a powerful potential tool for assessing 
the content of not only proteins, but also polysaccharides in oyster mushrooms, which have culinary and medicinal value. Quantification of proteins and glucans is especially important for the characterization of fungi, as it allows determination of the efficiency of cultivation and the most appropriate time for harvesting. In addition, it is known that different parts of the basidiocarp (stems, caps and spores) can differ significantly in biopolymer composition. The universal character of vibration spectroscopy allows these methods to be applied in the analysis of other types of edible mushrooms, of course, taking into account the peculiarities of their composition. Nevertheless, this approach can be proposed as an alternative to the widely used expensive and time-consuming analytical methods.

Author Contributions: Conceptualization, A.S. and P.K.; methodology, E.B. and R.B.; software, M.S. and I.Š.; validation, M.S. and I.Š.; formal analysis, E.B., R.B. and L.S.; investigation, E.B., R.B. and A.S.; resources, I.J.; data curation, E.B. and L.S.; writing—original draft preparation, E.B. and R.B.; writing-review and editing, E.B., R.B. and A.S.; supervision, A.S. and J.Č.; project administration, J.Č. and A.S.; funding acquisition, P.K., I.J. and A.S. All authors have read and agreed to the published version of the manuscript.

Funding: This research was funded by the Ministry of Agriculture of the Czech Republic, project number QK1910209, and by Specific University Research of UCT Prague, project number 21-SVV/2020.

Acknowledgments: The authors are grateful to Ing. Rudolf Ryzner for the supply of grown oyster mushrooms (basidiocarps) used for experiments. The authors also thank Ekaterina Lavrova, Kristina Panušková and Aneta Machalíková for technical support in sample preparation and analysis.

Conflicts of Interest: The authors declare no conflict of interest.

\section{References}

1. de Carvalho, C.S.M.; Sales-Campos, C.; de Andrade, M.C.N. Mushrooms of the Pleurotus genus: A review of cultivation techniques. Interciencia 2010, 35, 177-182.

2. Corrêa, R.C.G.; Brugnari, T.; Bracht, A.; Peralta, R.M.; Ferreira, I.C. Biotechnological, nutritional and therapeutic uses of Pleurotus spp. (Oyster mushroom) related with its chemical composition: A review on the past decade findings. Trends Food Sci. Technol. 2016, 50, 103-117. [CrossRef]

3. Carrasco-González, J.A.; Serna-Saldívar, S.O.; Gutiérrez-Uribe, J.A. Nutritional composition and nutraceutical properties of the Pleurotus fruiting bodies: Potential use as food ingredient. J. Food Compos. Anal. 2017, 58, 69-81. [CrossRef]

4. Kalač, P. A review of chemical composition and nutritional value of wild-growing and cultivated mushrooms. J. Sci. Food Agric. 2013, 93, 209-218. [CrossRef] [PubMed]

5. Synytsya, A.; Míčková, K.; Jablonský, I.; Sluková, M.; Čopíková, J. Mushrooms of genus Pleurotus as a source of dietary fibres and glucans for food supplements. Czech J. Food Sci. 2009, 26, 441-446. [CrossRef]

6. Patel, Y.; Naraian, R.; Singh, V.K. Medicinal properties of Pleurotus species (Oyster mushroom): A review. World J. Fungal Plant Biol. 2012, 3, 1-12.

7. Zhu, F.; Du, B.; Bian, Z.; Xu, B. $\beta$-Glucans from edible and medicinal mushrooms: Characteristics, physicochemical and biological activities. J. Food Compos. Anal. 2015, 41, 165-173. [CrossRef]

8. Rop, O.; Mlcek, J.; Jurikova, T. $\beta$-Glucans in higher fungi and their health effects. Nutr. Rev. 2009, 67, 624-631. [CrossRef]

9. Ma, G.; Yang, W.; Mariga, A.M.; Fang, Y.; Ma, N.; Pei, F.; Hu, Q. Purification, characterization and antitumor activity of polysaccharides from Pleurotus eryngii residue. Carbohydr. Polym. 2014, 114, 297-305. [CrossRef]

10. Zhang, Y.; Dai, L.; Kong, X.; Chen, L. Characterization and in vitro antioxidant activities of polysaccharides from Pleurotus ostreatus. Int. J. Biol. Macromol. 2012, 51, 259-265. [CrossRef]

11. Zhang, Y.; Hu, T.; Zhou, H.; Jin, G.; Yang, Y. Antidiabetic effect of polysaccharides from Pleurotus ostreatus in streptozotocin-induced diabetic rats. Int. J. Biol. Macromol. 2016, 83, 126-132. [CrossRef] [PubMed]

12. Smiderle, F.; Olsen, L.; Carbonero, E.; Marcon, R.; Baggio, C.; Freitas, C.; Santos, A.; Torri, G.; Gorin, P.; Iacomini, M. A 3-O-methylated mannogalactan from Pleurotus pulmonarius: Structure and antinociceptive effect. Phytochemistry 2008, 69, 2731-2736. [CrossRef] [PubMed]

13. Sun, Y.-X.; Liu, J. Purification, structure and immunobiological activity of a water-soluble polysaccharide from the fruiting body of Pleurotus ostreatus. Bioresour. Technol. 2009, 100, 983-986. [CrossRef] [PubMed] 
14. Synytsya, A.; Míčková, K.; Synytsya, A.; Jablonský, I.; Spěváček, J.; Erban, V.; Kováříková, E.; Čopíková, J. Glucans from fruit bodies of cultivated mushrooms Pleurotus ostreatus and Pleurotus eryngii: Structure and potential prebiotic activity. Carbohydr. Polym. 2009, 76, 548-556. [CrossRef]

15. Deepalakshmi, K.; Sankaran, M. Pleurotus ostreatus: An oyster mushroom with nutritional and medicinal properties. J. Biochem. Technol. 2014, 5, 718-726.

16. Alam, N.; Yoon, K.N.; Lee, T.S.; Lee, U.Y. Hypolipidemic Activities of Dietary Pleurotus ostreatus in Hypercholesterolemic Rats. Mycobiology 2011, 39, 45-51. [CrossRef] [PubMed]

17. Schneider, I.; Kressel, G.; Meyer, A.; Krings, U.; Berger, R.G.; Hahn, A. Lipid lowering effects of oyster mushroom (Pleurotus ostreatus) in humans. J. Funct. Foods 2011, 3, 17-24. [CrossRef]

18. Vasudewa, N.; Abeytunga, D.; Ratnasooriya, W. Antinociceptive Activity of Pleurotus ostreatus, an Edible Mushroom, in Rats. Pharm. Biol. 2007, 45, 533-540. [CrossRef]

19. Jayakumar, T.; Ramesh, E.; Geraldine, P. Antioxidant activity of the oyster mushroom, Pleurotus ostreatus, on CCl4-induced liver injury in rats. Food Chem. Toxicol. 2006, 44, 1989-1996. [CrossRef]

20. Jedinak, A.; Dudhgaonkar, S.; Wu, Q.; Simon, J.E.; Sliva, D. Anti-inflammatory activity of edible oyster mushroom is mediated through the inhibition of NF-kB and AP-1 signaling. Nutr. J. 2011, 10, 52. [CrossRef]

21. Karácsonyi, S.; Kuniak, L. Polysaccharides of Pleurotus ostreatus: Isolation and structure of pleuran, an alkali-insoluble $\beta$-d-glucan. Carbohydr. Polym. 1994, 24, 107-111. [CrossRef]

22. Jesenak, M.; Majtan, J.; Rennerova, Z.; Kyselovic, J.; Banovcin, P.; Hrubisko, M. Immunomodulatory effect of pleuran ( $\beta$-glucan from Pleurotus ostreatus) in children with recurrent respiratory tract infections. Int. Immunopharmacol. 2013, 15, 395-399. [CrossRef]

23. Tong, H.; Xia, F.; Feng, K.; Sun, G.; Gao, X.; Sun, L.; Jiang, R.; Tian, D.; Sun, X. Structural characterization and in vitro antitumor activity of a novel polysaccharide isolated from the fruiting bodies of Pleurotus ostreatus. Bioresour. Technol. 2009, 100, 1682-1686. [CrossRef] [PubMed]

24. Curvetto, N.; Figlas, D.; Devalis, R.; Delmastro, S. Growth and productivity of different Pleurotus ostreatus strains on sunflower seed hulls supplemented with $\mathrm{N}-\mathrm{NH} 4+$ and/or Mn(II). Bioresour. Technol. 2002, 84, 171-176. [CrossRef]

25. Meenu, M.; Xu, B. Application of vibrational spectroscopy for classification, authentication and quality analysis of mushroom: A concise review. Food Chem. 2019, 289, 545-557. [CrossRef]

26. Baeva, E.; Bleha, R.; Lavrova, E.; Sushytskyi, L.; Čopíková, J.; Jablonsky, I.; Klouček, P.; Synytsya, A. Polysaccharides from Basidiocarps of Cultivating Mushroom Pleurotus ostreatus: Isolation and Structural Characterization. Molecules 2019, 24, 2740. [CrossRef]

27. Bekiaris, G.; Tagkouli, D.; Koutrotsios, G.; Kalogeropoulos, N.; Zervakis, G.I. Pleurotus Mushrooms Content in Glucans and Ergosterol Assessed by ATR-FTIR Spectroscopy and Multivariate Analysis. Foods 2020, 9, 535. [CrossRef]

28. Mikola, E.; Geösel, A.; Stefanovits-Bányai, É.; Fodor, M. Quantitative determination of macro components and classification of some cultivated mushrooms using near-infrared spectroscopy. J. Food Process. Preserv. 2020, 44, 14540. [CrossRef]

29. Gomba, G.K.; Synytsya, A.; Švecová, P.; Čopíková, J.; Coimbra, M. Distinction of fungal polysaccharides by N/C ratio and mid infrared spectroscopy. Int. J. Biol. Macromol. 2015, 80, 271-281. [CrossRef] [PubMed]

30. Oberle, J.; Dighton, J.; Arbuckle-Keil, G.A. Comparison of methodologies for separation of fungal isolates using Fourier transform infrared (FTIR) spectroscopy and Fourier transform infrared-attenuated total reflectance (FTIR-ATR) microspectroscopy. Fungal Biol. 2015, 119, 1100-1114. [CrossRef] [PubMed]

31. Qi, L.-M.; Zhang, J.; Liu, H.-G.; Li, T.; Wang, Y. Fourier transform mid-infrared spectroscopy and chemometrics to identify and discriminate Boletus edulis and Boletus tomentipes mushrooms. Int. J. Food Prop. 2017, 20, S56-S68. [CrossRef]

32. Fujihara, S.; Kasuga, A.; Aoyagi, Y.; Sugahara, T. Nitrogen-to-Protein Conversion Factors for Some Common Edible Mushrooms. J. Food Sci. 1995, 60, 1045-1047. [CrossRef]

33. Braaksma, A.; Schaap, D. Protein analysis of the common mushroom Agaricus bisporus. Postharvest Biol. Technol. 1996, 7, 119-127. [CrossRef]

34. Wiercigroch, E.; Szafraniec, E.; Czamara, K.; Pacia, M.Z.; Majzner, K.; Kochan, K.; Kaczor, A.; Barańska, M.; Malek, K. Raman and infrared spectroscopy of carbohydrates: A review. Spectrochim. Acta Part A Mol. Biomol. Spectrosc. 2017, 185, 317-335. [CrossRef] [PubMed] 
35. Gutiérrez, A.; Prieto, A.; Martínez, M.J. Structural characterization of extracellular polysaccharides produced by fungi from the genus Pleurotus. Carbohydr. Res. 1996, 281, 143-154. [CrossRef]

36. Šandula, J.; Kogan, G.; Kačuráková, M.; Machová, E. Microbial (1 $\rightarrow 3)-\beta$-D-glucans, their preparation, physico-chemical characterization and immunomodulatory activity. Carbohydr. Polym. 1999, 38, 247-253. [CrossRef]

37. Unursaikhan, S.; Xu, X.; Zeng, F.; Zhang, L. Antitumor activities of O-sulphonated derivatives of $(1 \rightarrow 3)$-glucans from different Lentinus edodes. Biosci. Biotechnol. Biochem. 2006, 70, 38-46. [CrossRef] [PubMed]

38. Wang, T.; Deng, L.; Li, S.; Tan, T. Structural characterization of a water insoluble $\alpha$-(1 $\rightarrow 3$ )-D-glucan isolated from the Penicillium chrysogenum. Carbohydr. Polym. 2007, 67, 133-137. [CrossRef]

39. Liu, G.; Song, D.; Zhao, D.; Liu, J.-H.; Zhou, Y.; Ou, J.; Sun, S. A study of the mushrooms of boletes by Fourier transform infrared spectroscopy. In Proceedings of the ICO20: Biomedical Optics, Changchun, China, 2 February 2006; Volume 6026. [CrossRef]

40. Cárdenas, G.; Cabrera, G.; Taboada, E.; Miranda, S.P. Chitin characterization by SEM, FTIR, XRD, and13C cross polarization/mass angle spinning NMR. J. Appl. Polym. Sci. 2004, 93, 1876-1885. [CrossRef]

41. Kong, J.; Yu, S. Fourier Transform Infrared Spectroscopic Analysis of Protein Secondary Structures. Acta Biochim. Biophys. Sin. 2007, 39, 549-559. [CrossRef]

42. Ibrahim, M.; Nada, A.; Kamal, D.E. Density functional theory and FTIR spectroscopic study of carboxyl group. Ind. J. Pure Appl. Phys. 2005, 43, 911-917.

43. Miyazawa, M.; Sonoyama, M. Second Derivative near Infrared Studies on the Structural Characterisation of Proteins. J. Near Infrared Spectrosc. 1998, 6, A253-A257. [CrossRef]

44. Wang, J.; Sowa, M.G.; Ahmed, M.K.; Mantsch, H.H. Photoacoustic Near-Infrared Investigation of Homo-Polypeptides. J. Phys. Chem. 1994, 98, 4748-4755. [CrossRef]

45. Workmanjr, J. Interpretive Spectroscopy for Near-Infrared. Appl. Spectrosc. Rev. 1996, 31, 251-320. [CrossRef]

46. López, M.G.; García-González, A.S.; Franco-Robles, E. Carbohydrate Analysis by NIRS-Chemometrics. In Developments in Near-Infrared Spectroscopy; IN TECH: München, Germany, 2017; Volume 10, p. 67208. [CrossRef]

47. Ma, Y.; He, H.; Wu, J.; Wang, C.; Chao, K.; Huang, Q. Assessment of Polysaccharides from Mycelia of genus Ganoderma by Mid-Infrared and Near-Infrared Spectroscopy. Sci. Rep. 2018, 8, 1-10. [CrossRef]

48. Rygula, A.; Majzner, K.; Marzec, K.M.; Kaczor, A.; Pilarczyk, M.; Baranska, M. Raman spectroscopy of proteins: A review. J. Raman Spectrosc. 2013, 44, 1061-1076. [CrossRef]

49. Noothalapati, H.; Sasaki, T.; Kaino, T.; Kawamukai, M.; Ando, M.; Hamaguchi, H.-O.; Yamamoto, T. Label-free Chemical Imaging of Fungal Spore Walls by Raman Microscopy and Multivariate Curve Resolution Analysis. Sci. Rep. 2016, 6, 27789. [CrossRef]

50. Synytsya, A.; Novák, M. Structural diversity of fungal glucans. Carbohydr. Polym. 2013, 92, 792-809. [CrossRef]

51. Ruthes, A.C.; Smiderle, F.R.; Iacomini, M. Mushroom heteropolysaccharides: A review on their sources, structure and biological effects. Carbohydr. Polym. 2016, 136, 358-375. [CrossRef]

Publisher's Note: MDPI stays neutral with regard to jurisdictional claims in published maps and institutional affiliations.

(C) 2020 by the authors. Licensee MDPI, Basel, Switzerland. This article is an open access article distributed under the terms and conditions of the Creative Commons Attribution (CC BY) license (http://creativecommons.org/licenses/by/4.0/). 